\title{
Extent of Adoption And Usage of Mobile Phone Services in Empowering Women Entrepreneurs in Machakos County, Kenya
}

\author{
Consolata Mutisya, Dr. Wambui Kiai and Dr. Ndeti Ndati. \\ College of Humanities and Social Sciences, School of Journalism and Mass Communication University of \\ Nairobi, Kenya
}

\begin{abstract}
The purpose of this study was to assess the extent of adoption and usage of mobile phone technology to empower women entrepreneurs in Machakos County. The study adopted the use of Uses and Gratifications theory. Mixed method design was used. Systematic random sampling was used to select 350 respondents. Survey method was used to collect quantitative data. Quantitative data was analyzed using descriptive statistics and then presented in tables, figures and bar graphs. Purposive sampling was used to select 8 key informants and participants in the focus groups discussions. In-depth interviews and interview guide were used to collect qualitative data. Qualitative data was analyzed thematically and presented in narrative form. The study found that women entrepreneurs in Machakos had adopted and used the mobile phone services for business matters but they had only adopted the basic functions of the mobile phone and specially voice communication at (53.6\%) and SMS at (21.1\%) of the respondents. Most women entrepreneurs rarely used the advanced applications of the mobile phone with e-banking having the least used service in the mobile phone. Service like the internet had below average users at $17.5 \%$ of the respondents. The findings showed that the mobile phone has changed the way of doing business. Women entrepreneurs have been increasingly turning to the mobile technology services which aid in business transactions and hence increased profits. On mobile phone accessibility and increase of profits due to mobile phone use showed that $77.1 \%$ of the women entrepreneurs said that using mobile phone technology services for their businesses had led to increased profits. The study established that social media had gained a rapid acceptance and popularity among the women entrepreneurs although their use was below average. Facebook was the most popular social medium amongst the entrepreneurs at $37 \%$. Its popularity among women entrepreneurs can be attributed to the fact that Facebook provides interactive and immediacy, two things that are highly desirable to entrepreneurs. The study concluded that women entrepreneurs have accepted the mobile phone as an important tool for running their businesses but they have not fully adopted all the services of the mobile phone and especially the advanced functions. It was recommended that women opinion leaders should encourage and support their members to adopt and use mobile phone technology services, and do a follow up to make sure the members adopt it fully.
\end{abstract}

Keywords: Women empowerment, Women Entrepreneurs and Mobile phone technology

\section{INTRODUCTION}

The term new media encompass the emergence of computerized, digital or networked information and communication technologies in the late part of the $20^{\text {th }}$ century. Most new technologies described as "New media" are digital, often having characteristics of being manipulated, networked, compressible, interactive and impartial (Herrington, 2009).

This study focused on mobile technology services as it is one of the forms of new media. The spread of mobile phones across the developing world is an example of most remarkable technology introduced the past decades. This technology has been facilitated by the use of affordable handsets and prepay cards which had enable its accessibility by hundreds of millions of first-time telephone owners to make calls and send text messages in their daily communication. However, new mobile users still live in informal cash economies, without access to financial services that others take for granted (Afrobaromter, 2013). Across the developing world, there are many people with mobile handsets than holding account in bank (Porteous, 2006).

\section{Mobile Technology}

Mobile technology has been adopted cellular communication. Mobile code division multiple access (CDMA) is a technology that has evolved speedily over the past years. Mobile phones, particularly Smartphone support a wide range of services such as multimedia services, messaging, access to Internet, email, wireless communications, business applications, photography and gaming. Such phones are referred to as smart phones as they offer more general computing capabilities. The technology allows the mobile population to use company resources and data. Whether your staffs are travelling to meetings, out on sales calls, working from a client-site 
Extent of Adoption And Usage of Mobile Phone Services in Empowering Women Entrepreneurs in..

or from anywhere on the globe, mobile phones can help them keep in touch, be productive, and make use of company resources (Chibba, 2009).

Mobile phone devices can also change the way a company does business - new technologies lead to new ways of working, and new products and services that can be offered to one's customers. They can make one's team more creative, efficient and valuable clients. Mobile technology allows organizations to have an exceptional level of connectivity between vendors, employees and customers. It enables workers to download applications which enable their devices to connect with others through social media such as Facebook, Twitter and LinkedIn. The firm can also use web-based applications to facilitate direct communication with their audiences in many ways (Chibba, 2009).

\section{Empowerment of women}

According to Kretschmer (2012), empowerment of women necessitates transformation of labour division as well as changes in ideologies prevalent on the roles and responsibilities of women and men. Empowerment helps achieve practical as well as strategic gender needs by enhancing self-reliance among women and acknowledging power dynamics rooted in gender class, ethnicity and age. Malhotra et al. (2002) in their differently view argue that "empowerment" has been used to advocate more often for certain types of intervention strategies and policies than to analyze them. This is demonstrated by a number of documents from the United Nations (UNDAW, 2001; UNCEF,2009; UKDID, 2000), and other organizations.

For women to get empowerment economically, they have no option but to compete in a world male-dominated. The interest of this study was to assess whether cell phone is an empowering tool for women or not. Kretschmer (2012) posits that women empowerment is about the processes by which women who have been denied the ability to make strategic life choices. The ability of women to exercise choice as they incorporate three inter-related dimensions such as: resources, agency and achievements. He continues to argue that these three dimensions of choice are indivisible in determining how to measure women empowerment. For cell phones to contribute to empowerment they have to fit within the three dimensions.

Entrepreneurship is perceived as the engine of growth in Kenya because of its key role in economic development. The sector provided a lot of opportunities for employment as well as market for goods and services thus steering competition and innovation (KIPPRA, 2002). Entrepreneurship comprises about $75 \%$ of all businesses, employ 4.6 million people (30\%), accounts for $87 \%$ of new jobs created and contributes $18.4 \%$ of the GDP (GOK, 2013). The Kenyan government considers the sector as the center of industrial development and has held different development strategies (GOK, 2010). However the sector faces binding challenges that make it impractical for it to realize its full potential and deliver to the government expectations. The challenges included limited access to market, information, finances and technology and the drawback of policies which do not business environment among others (GOK, 2005).

Information Technology (IT) is identified as an enabler of other sectors, presenting enormous opportunities for entrepreneurs to improve market access (GOK, 2007). Mobile telephony has become a part of everyday life for millions of people and business organizations across worldwide. People in the business world nowadays consider the ability to communicate by mobile phones as necessary and ordinary (Donner \& Escobari, 2009). The significance of mobile telecommunications services beyond basic person-to-person voice communication cannot be overemphasized. Mobile phones have become absolutely crucial for anyone doing business today due to the fact that they provide flexibility and efficiency in communication that has never existed before, and has quickly become expected in the fast moving world of modern business (Joseph, 2005).

Mobile phone services have become an indispensable tool in the highly globalized, knowledge economy. Today entrepreneurs can carry out business through their mobile phone thanks to WhatsApp, face books, M-Pesa, Airtel money and others such as OLX. This is because one only needs to take a photo of the product he/she is selling post it through WhatsApp, negotiate through the use of WhatsApp, facebook or SMS, and upon agreement receive payment through M-Pesa or Airtel money. This saves the seller and the buyer operation costs which leads to improved profits and thus raising the living standards of Kenyans. This has led to their finding a place in the government of the day which is encouraging youth and women to engage in business in order to earn a living.

\subsection{Problem Statement}

Despite the potential of enterprises run by women to boost local economy (USAID, 2001) briefs indicate that women owned enterprises grow less rapidly and are likely to close sooner than male counterparts. According to Kalundo (2012), women's productive activities were concentrated in micro-enterprises such as hawking, retail, manufacturing in small scale and market trade periodicals. In this regard women were concentrated in enterprises that conform to their traditional gender roles, mostly in food processing and garment making. This situation is evident in Kenya (GoK, 2009). This choice of business also defines profitability of the enterprise. Women owned enterprises generated less revenue compared to revenues generated by enterprises owned by men, which earned $74 \%$ more (Central Bureau of Statistics, 2011)

DOI: $10.9790 / 0837-2107034859 \quad$ www.iosrjournals.org $\quad 49 \mid$ Page


Extent of Adoption And Usage of Mobile Phone Services in Empowering Women Entrepreneurs in..

Reynolds (2004) posits that women entrepreneurs are unlikely to adopt more sophisticated technologies if they are not familiar with the basic ones as opposed to men. That's why entrepreneurships owned by men grew faster at a rate of $32 \%$ annually as compared to $16 \%$ of those owned by women. This is because of the limited number of women who have technical knowledge. Women are still observed to be lagging behind in development issues and lacks empowerment traits.

Many women businesses are still missing the huge potential benefits of using mobiles technology as a part of their business enhancement (Ikiara, 2001). The different modes of communication embedded in most mobile phones including voice, SMS, radio, TV, interpersonal and group communications don't seem to improve the situation (AFFRI, 2009) Most of them are still clinging to the old fashion mode of communication that include newspapers, radio, banners and posters, and the use of traditional yet ineffective landline when it comes to interpersonal communication. This has resulted to some of them despite, being in the market for long, being overtaken if not edged out of the business by those that utilize mobile telephony because they are unable to achieve their set business goals (Svanaes, et al, 2010). This study sought to assess the extent of adoption and usage of mobile phone services in empowering women entrepreneurs in Machakos County, Kenya.

\section{LITERATURE REVIEW}

This section presents theoretical and empirical review

\subsection{Uses and gratifications theory}

Uses and gratifications theory (UGT) as an approach helps in understanding how and why people actively seek out specific media to satisfy their specific needs. UGT is an audience-centered approach to understand mass communication (Severin and Tankard, 1997). Diverging from other media effect theories that question "what does media do to people?" UGT focuses on "what do people do with media?" (Katz, 1959: 54).

This communication theory is positivistic in its approach, based in the socio-psychological communication tradition, and focusing on communication at the mass media scale (Lynn, 2013). The driving question of UGT is: what do they use media for and why they use them? UGT discusses how users deliberately choose media that will satisfy given needs and allow one to enhance knowledge, relaxation, social interactions/companionship, diversion, or escape (Tankard, 2000).

It assumes that audience members are not passive consumers of media. The audience normally has power over their media consumption as they assume an active role in integrating and interpreting media into their own lives. Comparing this with other theoretical perspectives, UGT holds that audience is responsible for choosing media to meet their desires and needs to achieve gratification. This theory would imply then that the media compete against other information sources to gratify viewers (Katz, 2011)

Levy and Windahl (1985:35) provide a good description of what it means to be an "active consumer" of media: "Commonly as understood by researchers doing gratification studies, the term "audience activity" means a voluntaristic and selective orientation by audiences towards the communication process. In brief, it suggests that media use is motivated by needs and goals that are defined by members of the audience themselves, and that actively participating in the process of communication may limit, facilitate, or influence the gratifications thus the effects are associated with exposure. Current thinking also proposes that audience activity is best conceptualized as a variable construct, with audiences showing varying kinds and degrees of activity."

The use of mobile phones by women owning business is propagated by the fact they want to get information, reach their customers and also make business transactions. So to them the mobile phone services meet their economic need and hence gratify them. Mobile phones, a comparatively new technology have been found to attract many uses and gratifications. This is propagated by their mobility nature, their accessibility which is normally constant and their characteristic that they have options to add and access content. In general, people use mobile phones for the following uses and gratifications: affection/sociability, entertainment, instrumentality (information seeking, talking to business partners and coordination of business), psychological reassurance, fashion/status, mobility, and immediate access (Blumler, 2011).

\subsection{Extent of adoption and Usage of Mobile Phone Applications in Empowering Women Entrepreneurs}

The use of mobile phones has spurred a great economic development in African countries. Some of the specific features of mobile phone technology is the mobile phone-based products and services offering beyond basic messaging in form of texts and voice calls. Despite the fact that mobile phone services have more often focused on applications for entertainment, in developed countries, the same applications have been used to provide opportunities for disseminating information on agricultural prices health care monitoring and money ransferring in developing countries. 
Extent of Adoption And Usage of Mobile Phone Services in Empowering Women Entrepreneurs in..

The rapid adoption of M-Pesa and other m-money transfer services is not taking the population by surprise as it has impacted on the financial development not only in Kenya but also in other countries in the subSaharan Africa. It is estimated that less than 30 percent of East and Southern African population have a formal bank account, where 9 percent are in Tanzania to 63 percent in South Africa (FinMark Trust, 2008). Kenya had only 450 bank branches and 600 automatic teller machines in 2006 (Vaughan, 2007). Kenyans primarily sent money via Western Union or post office, intermediaries (such as bus drivers), or through friends or relatives apart from the formal financial systems. The use of Western Union were perceived to be more secure but were more often very expensive and not available in remote rural areas. On the other hand, sending money through transport services or via relatives and friends is more accessible but entails high risk of theft. Evidence shows that the cost of sending Kshs 1,000 (US\$15) from Nairobi to the western region though M-Pesa by 2008 was two-fifths the cost of the post official rate and one-fiftieth the cost of sending it through buses (Morawczynski, 2009). As such, the use of mobile phone technology by women entrepreneurs have been influenced by many of factors which also appear affect their empowerment in business. According to Cracknell (2004), the different type of enterprise that women choose to run is normally gendered.

Skills base is a major determinant of business choice among women. Gakure (2004) noted that when women require to earn more money they normally turn to their domestic skills to explore the micro-enterprises. The business choice started was largely gendered in the first place. This is in recognition of the biasness in education and training which influences the career choices as defined the cultural setting. Business choice thus defines the information required which in turn define the ICT tools (Kalundo, 2004).

Mobile phone usage is very high among the SMEs operating in the Kenyan economy. This is evidenced by the findings of a study by Maru (2004) carried out among 50 entrepreneurs (72\% women) in Eldoret where it was found that there was a very high penetration of mobile phone usage. Among ICTs usage, $88 \%$ of what was commonly used were mobile phones. The respondents mentioned that they were able to communicate and deliver products through the use of ICT faster than they would if it was not there. Specific advantage realized through the use of mobile phones included: faster and easier decision making, faster transfer of information, reduced transaction and communication costs, quicker sales, and easy access to products and services. Maru (2004) posits that the most important information required regarded suppliers and the market. Mureithi (2005) further reported that there was high usage mobile phone by MSEs owners in Kariobangi Light Industries in Nairobi known with 450 plots, at $93.8 \%$ against usage of the fixed line of $29.7 \%$. Among the users without a landline, $22.0 \%$ mentioned that they did not need one.

Women support groups also has influence on the tools they use in accessing information. Evidence show that use close, support groups for their businesses owned by their spouses, relatives and their own groups. According to Hisrich and Peters (2002), women were found to consult their spouse on major decisions in their enterprises. On the other hand, it was revealed that men consulted their spouses last. Through informal consultation, information was found to follow the pattern whereby mobile phones was defined as one of the most effective communication tools. Business needs and the use of the information were more often informed by the motivation for first establishing the business.

In a study done by Imbaya (2004) in Eldoret seeking to determine the extent of entrepreneurial disposition and how it effect women performance. The study also entailed searching for the social factors affecting the development and growth of women enterprises. A total of 175 women enterprises were studied where the findings revealed that most of them perform poorly as justified by the fact that they lacked locus of control. The decision to go into business was determined by people other than themselves as indicated by $(68.6 \%)$, followed by husband $(24.6 \%)$, parents $(27.4 \%)$ and friends $(13.1 \%)$. The decision to start a business followed a clear description of their situation by only $31.4 \%$ of the women. Owning a business enterprise was therefore described by as a necessity rather than an opportunity. To achieve growth, women therefore need to redefine their situation in order to see owning an enterprise as a means to their prosperity.

A study by Kibas and K'Aol (2004) of 24 SMEs which were considered to be successful with over 5 years' operation in Kenya revealed that that $64 \%$ of business people (comprising 29.2\% women) entered business due to the opportunity they saw. As such, the decision to start a business was deemed critical for success.

According Huyer et al. (2005), women were losing as far as the expansion of business networks by relying mobile phones rather through the Internet. By relying information on the phone, they limited their contacts to informal family networks thus limiting their potential for entrepreneurship growth. Huyer et al. (2005) found that men frequently felt that women freedom to have mobile phones destabilized their marital relationships. In this was evidenced by the fact that in many cases men monitored mobile phone and Internet usage by their spouses. While mobile phone demonstrated a gain in Chennai over reliance on it was deemed in Southern Africa as it caused distress in women's relationships with men (Huyer et al. 2005).

Mutwiri (2013) investigated mobile phone and rural livelihoods among smallholder farmers in Machakos County, Kenya. The findings of the study revealed that the use of mobile phone technology improved the livelihood of $\mathrm{d}$ farmers by increasing their income while reducing losses, though it did not directly 
Extent of Adoption And Usage of Mobile Phone Services in Empowering Women Entrepreneurs in..

affect the livelihood smallholder farmers but helped them to get permanent jobs or off-farm part-time. It was concluded that mobile phones are valued due to the fact they keep farmers connected to their friends and relatives but not necessarily used to access and share agricultural and rural livelihood information. He further found that the mobile phones had the potential to improve the livelihoods among smallholder farmers but was not optimized due to lack of training and awareness.

\section{METHODOLOGY}

The research was conducted in Machakos Municipality of Machakos county. Machakos County is a county of Kenya and its capital is Machakos town. Its largest town is Machakos town, Kenya's first administrative headquarters. This study used mixed methods research approach. The study population was women entrepreneurs in Machakos municipality. Systematic sampling technique was used to select 350 women entrepreneurs. Purposive sampling technique was used to select key informants. The Key informant interviews comprised of 2 women group leaders comprising of the chairlady and the secretary, 2 officials in charge of ICT and business from the service providers (one from Safaricom and the other from Airtel), 2 officials from the Ministry of Information Communication and Technology and 2 county officials in charge of business development and licensing. Questionnaires, interview schedules and focus group discussions were used to collect the data. Qualitative data was analysed by use of descriptive statistics such as frequencies and percentages while qualitative data was analysed using thematic analysis technique.

\section{FINDINGS OF THE STUDY}

4.1 The extent of mobile adoption in business by Machakos municipality women entrepreneurs Women Entrepreneurs mobile phone ownership

Table 1. Mobile phone ownership

\begin{tabular}{|l|l|l|}
\hline Response & Frequency & Percentages \\
\hline Yes & 329 & 99.1 \\
\hline No & 1 & 0.3 \\
\hline No answer & 2 & 0.6 \\
\hline Total & $\mathbf{3 3 2}$ & $\mathbf{1 0 0}$ \\
\hline
\end{tabular}

The study found out that the majority $(99.1 \%)$ of the women entrepreneurs own their mobile phones for purposes of doing businesses. This is similar to the studies carried out by (Strategic Growth Concepts, 2013 \& Donner \& Escobari, 2010) both in developed and developing countries case Kenya and Uganda, where it was established that majority of women entrepreneurs were using mobile phone technology services in their businesses. Two key informants from the service providers, Safaricom (S1) and Airtel (S2), concurred that almost all women entrepreneurs in the county owned a registered mobile phones. From their data base, $90 \%$ of businesses owned by women had a registered mobile phone. A key informant who's the chairlady of a women group informed the researcher that all women in the group owned one or two mobile phones, since mobile phone is their tool of trade. She quipped,

L1: Doing business here without a mobile phone is like going to dig without a hoe. I don't know what I would do without a mobile phone. It has become part of our lives. You cannot even be a member of our group if you have no mobile phone because you will be the odd one out.

All participants in both focus groups had mobile phones for their businesses and some had a mobile phone each for the two networks of Safaricom and Airtel. One participant said,

W2: The mobile phone is the most important partner in business, you cannot operate without one. You can survive in business without workers but you can't survive without a mobile phone because you can perform many duties with it in your premise as you sit."

Type of social media mostly used by women entrepreneurs

Table 2. Type of social media used for business

\begin{tabular}{|l|l|l|}
\hline Social media & Frequency & Percentages \\
\hline Facebook & 123 & 37 \\
\hline Twitter & 19 & 5.7 \\
\hline Linked In & 1 & 0.3 \\
\hline Tag & 4 & 1.2 \\
\hline WhatsApp & 79 & 23.8 \\
No answer & 106 & 31.9 \\
\hline Total & $\mathbf{3 3 2}$ & $\mathbf{1 0 0 . 0}$ \\
\hline
\end{tabular}


Extent of Adoption And Usage of Mobile Phone Services in Empowering Women Entrepreneurs in..

The study found that most women entrepreneurs use Facebook (37\%) and whatsApp (23.8\%) social media to reach out to their customers and market their products. This finding is in agreement with the study done by (Cherie Blair Foundation for Women, 2012) which found that most marketing of business by women entrepreneurs is done through social media and especially facebook although the results show that the usage is below average. This contradicts the comments of the focus groups, because all the participants in the focus groups said they used whatsApp more than Facebook because whatsApp is easy to use once it's downloaded in the phone, one does not need an email address and password to open it like Facebook. One participant quipped,

W6: I always forget the password to my Facebook address therefore I have stopped using it and use whatsApp which doesn't need password. In fact, most of my customers prefer that we communicate through whatsApp because it is easy and cheap as long as you buy daily bundles.

A manager at Safaricom service provider informed the researcher that most women only inquire about and ask for assistance to download whatsApp more than any other social media. WhatsApp has gained dominance over the other social media channels since it is easy to use. This finding also tallies with the TAM which stipulates that women adopt easy to use technology and avoid any technology which they feel is hard and requires learned skill (Kotelnikov, 2007).

\section{Accessing information by using the mobile phone}

Table 3. Information accessibility

\begin{tabular}{|l|l|l|}
\hline Response & Frequency & Percentages \\
\hline Strongly agree & 122 & 36.7 \\
\hline Agree & 176 & 53 \\
\hline Not sure & 20 & 6.1 \\
\hline Disagree & 7 & 2.1 \\
\hline Strongly disagree & 4 & 1.2 \\
No answer & 3 & 0.9 \\
\hline Total & $\mathbf{3 3 2}$ & $\mathbf{1 0 0 . 0}$ \\
\hline
\end{tabular}

Most of the respondents interviewed $(89.7 \%$ ) agreed that mobile technology services enables them to access information. This tallies with the study done by (World Bank, 2012) on information communication for development. The study found that mobile phones enable entrepreneurs to access information on market needs and financial information. It also concurs with the study done by (Muturi, 2012) which found that rural farmers depend on the mobile phone to access information about farming. The literature reviewed showed that in India and the USA, women have adopted the mobile phone to access information about the markets for their products; thereby improving their businesses (Joseph, 2005).A key informant who is the secretary of a women group acknowledged that mobile phone enables the group members to access information about their businesses and about the women group. She said,

L2: We send information to our members on issues of our group, because of our busy schedules; we don't meet often but use our mobile phones to pass information to one another. I send notices of our next meeting through the mobile phone and members can access the meeting minutes through their emails addresses in their mobile phones, although many do not read the minutes because they don't know how to access their emails.

A key informant in the ministry of ICT (T2) informed the researcher that the ministry is taking advantage of the accessibility of the mobile phone to pass policy information to citizens instead of using electronic media like radio and TV and the ministry has noticed a positive impact, and this means that information is more accessible through the mobile phone.

Business type owned by women entrepreneurs in Machakos municipality

Tabl 4. Type of business

\begin{tabular}{|l|l|l|}
\hline Type of business & Frequency & Percentages \\
\hline Kiosk & 83 & 25 \\
\hline Retail shop & 150 & 45.2 \\
\hline Wholesale & 65 & 19.6 \\
\hline Distributor & 6 & 1.8 \\
\hline Producer & 7 & 1.8 \\
\hline No answer & 22 & 6.6 \\
\hline Total & $\mathbf{3 3 2}$ & $\mathbf{1 0 0 . 0}$ \\
\hline
\end{tabular}


Extent of Adoption And Usage of Mobile Phone Services in Empowering Women Entrepreneurs in..

The study found that most women entrepreneurs interviewed owned kiosks, retail shops and wholesales shops at $89.8 \%$ and this agrees with the findings by (Donner \& Escobari, 2010) on mobile phone use by micro and small entrepreneurs in developing countries whose findings were that women entrepreneurs are gendered towards their domestic roles and that they shy away from difficult areas like distribution and production.

From the 12 participants in the two focus groups, only 2 women participants were in the distribution businesses, the rest owned a kiosk, a retail shop or a wholesale enterprise. None of them was in production. Skill base determines choice of business and when women want to earn money they turn to their domestic skills to exploit in the micro-enterprises (Gakure, 2004). This is cognizant of the cultural bias in education and training and subsequent career choices defined by cultural setting. Most African cultures perceive women as the weaker sex and hence when it comes to business, they can only perform the 'soft' businesses. The finding was also supported by a key informant from the county commission $(\mathrm{C} 1)$ in charge of business development, who said that most women who come to register their businesses are either in retail or service industry.

Ownership of business done by women entrepreneurs in Machakos Municipality

Table 5. Business ownership

\begin{tabular}{|l|l|l|}
\hline Form of business & Frequency & Percentages \\
\hline Sole proprietor & 250 & 75.3 \\
\hline Partnership & 80 & 24.1 \\
\hline No answer & 2 & 0.6 \\
\hline Total & $\mathbf{3 3 2}$ & $\mathbf{1 0 0 . 0}$ \\
\hline
\end{tabular}

Most business entrepreneurs interviewed are sole proprietors at $75.3 \%$ as compared to partnership at $24.1 \%$. By being sole proprietors, they are able to make strategic decisions about their businesses and on which technology suits their businesses. The findings concur with a study done by (Malhotra, Sidney and Carol 2002) on measuring women empowerment whose findings were that women who are sole proprietors were more empowered as they could make their own decisions without depending on their partners to make decisions for them.

The findings tally with the information given to the researcher by an official in charge of business monitoring and evaluation at the county offices (C2). He said that $90 \%$ of all registered women enterprises were sole proprietors. The women set up the businesses themselves and manage them. He added that when women leave formal employment, through retrenchment, retirement or optional decision they turn to self-employment. They may also open businesses on the side while still formally employed and most of them are sole proprietors.

The focus group discussion members also supported these findings since all participants were sole proprietors of their businesses apart from one who had partnered with her sister. One participant said,

W3: When I got retrenched from formal job, I used the money paid to me to set up my supplies business. I didn't involve anybody even my husband lest the business failed to pick. I wanted to try the business alone so that I may learn first. I also realized that it was easier to register a sole proprietorship than any other business.

Women will only be empowered if they are able to make critical decisions on their social and economic status. It would be easier for them to adopt whatever technology they find useful for their business when they don't need to depend on anybody to make decisions for them.

\section{Type of Partnership Business}

Table 6. Partnership businesses carried out

\begin{tabular}{|l|l|l|l|}
\hline Type of Partnership & Frequency & Percentages \\
\hline & $\begin{array}{l}\text { Family } \\
\text { business }\end{array}$ & 80 & 24.1 \\
\cline { 2 - 4 } & $\begin{array}{l}\text { Women } \\
\text { groups }\end{array}$ & 20 & 6 \\
\cline { 2 - 4 } & No answer & 95 & 28.6 \\
\cline { 2 - 4 } & missing & 137 & 41.2 \\
\hline Total & $\mathbf{3 3 2}$ & $\mathbf{1 0 0}$ \\
\hline
\end{tabular}

The study found that $24.1 \%$ of the businesses were family businesses while $6 \%$ were women group businesses. This means that the married women consulted their spouses or other family members when running their businesses. This is in agreement with Hisrich and Peters (2002) that women consulted their spouse first on major decisions for their businesses. The findings are also in agreement with study a done by Imbaya (2004) on 
Extent of Adoption And Usage of Mobile Phone Services in Empowering Women Entrepreneurs in..

entrepreneurial disposition and its effects on performance among women. The study found that most performed poorly because of lack of locus of control. The decision to go into business was determined by people other than themselves. Women find it easier to start a family business in which they can be consulting family members.

\section{Application of mobile phones in business transactions}

Table 1. Use of mobile phone in business Transactions

\begin{tabular}{|l|l|l|}
\hline Response & Frequency & Percentages \\
\hline Yes & 289 & 87 \\
\hline No & 34 & 10.2 \\
\hline $\begin{array}{l}\text { I don't } \\
\text { know }\end{array}$ & 2 & 0.6 \\
\hline No answer & 7 & 2.1 \\
\hline Total & $\mathbf{3 3 2}$ & $\mathbf{1 0 0 . 0}$ \\
\hline
\end{tabular}

The research found that most women entrepreneurs used the mobile phones for business transactions $(87 \%)$. This agrees with the study done by (Kretschmer, 2012) on Information and Communication Technologies and Productivity Growth, whose findings were that most women acquired mobile phones in order to do business transactions from the comfort of their premises. It also agrees with Uses and Gratification theory which stipulates that users deliberately choose media that will satisfy given needs and allow one to enhance knowledge, social interactions and companionship (Tankard, 2000).

The key informant (T2) in the Ministry of ICT informed the researcher that the mobile phone is widely used by most entrepreneurs to transact business, as compared to other technologies in the county. All participants in the focus groups concurred with the findings. They all use their mobile phones to transact business. One participant said,

W4: I do almost all business transactions using my mobile phone. I send and withdraw money using my phone, I pay bills using my phone, I bank using my phone and I even call my clients. This phone does for me everything. If I was to pay people to transact all the businesses, I do I would be spending a lot of money to pay them.

Frequency of adoption and use of mobile technology in business

Table 8. Rate of application of mobile technology use in business

\begin{tabular}{|l|l|l|l|l|l|l|l|l|}
\hline Applications & Most Often & \multicolumn{2}{l|}{ Often } & \multicolumn{2}{l|}{ Rarely } & \multicolumn{2}{l|}{ No Answer } \\
\hline & $\mathrm{F}$ & $\%$ & $\mathrm{~F}$ & $\%$ & $\mathrm{~F}$ & $\%$ & $\mathrm{~F}$ & $\%$ \\
\hline M-Pesa & 112 & 49 & 86 & 38 & 24 & 10 & 7 & 3 \\
\hline M-shwari & 44 & 24 & 47 & 25 & 38 & 20 & 58 & 31 \\
\hline $\begin{array}{l}\text { Buying and selling products through } \\
\text { mobile phones }\end{array}$ & 72 & 24 & 113 & 38 & 36 & 12 & 41 & 13 \\
\hline $\begin{array}{l}\text { Frequency of applying mobile phone } \\
\text { in business transactions }\end{array}$ & 81 & 38 & 68 & 32 & 36 & 17 & 16 & 7 \\
\hline
\end{tabular}

The study found that the application of the mobile phone which was used most often was Mpesa at $87 \%$ and only $10 \%$ of the respondents rarely used it. This means that Mpesa was widely adopted as compared to Mshwari at 49\% and both services can be used to transact business. The difference may be because of lack of knowhow to use Mshwari as compared to Mpesa which was introduced earlier and is easier to use. According to the TAM theory, women avoid technology deemed as hard to use and only adopt the technology which they feel is easier to use and requires less learned skill (Kotelnikov, 2007).

A key informant from Safaricom Limited (S1) who is the Machakos branch manager informed the researcher that Mpesa service is the most used service in their organization. This may be due to the fact that Mpesa is easy to use and it can be used by both banked and unbanked. He said,

S1: Mpesa is so popular among the entrepreneurs, in fact we had to set a different counter because Mpesa inquiries where so many. Business people wanting to deposit or withdraw huge sums of money using their mobile phones come here because we always keep a high float for them.

$24 \%$ of the respondents agreed that they use mobile technology quite often to buy and sell their products. This means that mobile technology has been adopted by women entrepreneurs in transacting business although by a small percentage which contradicts with a study done by Komunte, Rwashana, \& Nabukenya 
Extent of Adoption And Usage of Mobile Phone Services in Empowering Women Entrepreneurs in..

(2012) on comparative analysis of mobile use by women entrepreneurs in Kenya and Uganda and found out that women entrepreneurs use the mobile quite often to sell and buy products both in Kenya and Uganda.

Only 2 out of 12 women respondents in the focus groups use the mobile phone to buy and sell their products using the mobile phone. The rest said that they didn't understand how to use many of the social sites like OLX, WhatsApp and facebook.

Table 9. Increase of profits due to Mobile phone use

\begin{tabular}{|l|l|l|}
\hline Response & Frequency & Percentages \\
\hline Yes & 258 & 77.7 \\
\hline No & 27 & 8.1 \\
\hline I don't know & 22 & 6.6 \\
\hline No answer & 25 & 7.5 \\
\hline Total & $\mathbf{3 2 2}$ & $\mathbf{1 0 0 . 0}$ \\
\hline
\end{tabular}

It was established from the field that majority $(77.7 \%)$ of the women entrepreneurs in Machakos County agreed that application of mobile technology had helped to increase the business turnover. This report agrees with the study that was conducted by (Hamerman, 2010) in the USA which found out that the majority of women entrepreneurs had opted to use mobile phones in business because it was the only way to increase their profits.

A Key informant (C1) from Machakos county office reported that there is increased turnover in women businesses and especially those who have adopted and use mobile technology services. Most women have opened new branches or have increased their stock. All respondents in the focus groups unanimously agreed that their businesses profits had increased substantially. One of them commented,

W10: Since I started using the mobile phone to transact business, my profits have more than doubled. I think it is because I can do so many things using the phone. Before I started using (the phone) I used to get less profit, such that there was no need to bank. I used to leave all the sales in my cash box. The profits were so little that I didn't see the need to waste time queuing in the bank to deposit such little amount. But nowadays, I bank almost on a daily basis. I can't dare leave the money there lest it is stolen.

\subsection{Summary of the findings of the Study}

The findings show that women entrepreneurs have embraced the mobile phone as an important gadget for their business. $99.1 \%$ of the respondents agreed that they owned a mobile phone. Only one respondent did not own a mobile phone. These findings are supported by the statistics in the literature reviewed which shows that by October 2012, Kenya had four licensed mobile phone providers with a total of 29.2 million subscribers between them and by the end of 2013, Kenya had 93\% mobile users (Praekelt,2011). According to Demombynes and Thegeya (2011) using Kenya Afro barometer surveys (2011), 80\% of adults in Kenyan own phones and another 10 percent have access to phone from in their households, and 3 percent used phones by someone outside their households. The study set out to investigate the extent of adoption and use of these mobile phones by women in their businesses.

The study found that women entrepreneurs in Machakos had adopted and used the mobile phone services for business matters but they had only adopted the basic functions of the mobile phone and specially voice communication at $(53.6 \%)$ and SMS at (21.1\%) of the respondents. Most women entrepreneurs rarely used the advanced applications of the mobile phone with e-banking having the least used service in the mobile phone. Service like the internet had below average users at $17.5 \%$ of the respondents. These findings are in agreement with the literature reviewed that women avoid any technology which they feel is hard and requires learned skill (Kotelnikov, 2007). They also agree with TAM which suggests that the acceptability of an information system is predicted by its perceived usefulness and ease of use. The ease of use is the extent to which one believes that the use of a particular system will be effortless. Most of the women entrepreneurs had basic education and this may be the reason they shied away from the more advanced mobile phone applications since they felt that they lacked the capability and skill to use the advanced applications. From the study, only a few women entrepreneurs attended any trainings and workshops to be sensitized on the use of the advanced applications. So the women entrepreneurs in Machakos missed on the benefits of using the advanced applications.

The findings show that the mobile phone has changed the way of doing business. Women entrepreneurs have been increasingly turning to the mobile technology services which aid in business transactions and hence increased profits. On mobile phone accessibility and increase of profits due to mobile phone use showed that $77.1 \%$ of the women entrepreneurs said that using mobile phone technology services for 
Extent of Adoption And Usage of Mobile Phone Services in Empowering Women Entrepreneurs in..

their businesses had led to increased profits. This is evidence that the mobile phone technology when harnessed well can improve entrepreneurships which could lead to better living standards for the women and their families and hence lead to empowerment. This claim is supported by Joseph (2005), who argues that it has become crucial for anyone doing business today to own a mobile phone due to the fact that it provides flexibility and efficiency and has become expected in the fast moving world of business. This was supported by the participants of the focus group discussions who all agreed that since they adopted mobile technology services in their businesses, their profits had increased remarkably.

In countries like the U.S.A where women have adopted mobile technology services in their businesses great transformation has been observed. The main drivers of this trend are, improved business practices and performance (Hamerman, 2010). The study established that social media had gained a rapid acceptance and popularity among the women entrepreneurs although their use was below everage. Facebook was the most popular social medium amongst the entrepreneurs at $37 \%$. Its popularity among women entrepreneurs can be attributed to the fact that Facebook provides interactive and immediacy, two things that are highly desirable to entrepreneurs. It can be used to market products and get new markets due to the high numbers of people using it. The current population of Facebook users in Kenya stands at 5 million which is $9.7 \%$ of the total Kenyan population (Internet world stats, 2015). The study contrasted with the discussion with the focus groups where a participant said;

W1: I always forget the password to my Facebook address therefore I have stopped using it and use WhatsApp which does need a password. In fact most of my customers prefer that we communicate through WhatsApp because it is easy and cheap as long as you buy daily bundles.I don't know how to use Twitter or Myspace and I have never tried because I think they are hard to learn.

Social networks such as My Space, YouTube, Twitter, WhatsApp and Facebook have been receiving a lot of public attention but very few women entrepreneurs in Machakos County use them. Social networks have become important avenues for marketing products and services among entrepreneurs (Kanyingi, 2011). Social networks have opened a wide market which if well harnessed by women entrepreneurs could lead to reaching new markets for their products and services.

The findings of this study show that $89.7 \%$ of those interviewed agreed that mobile technology services enable them to access information. The mobile phone has made information search easier and cheaper. Therefore, the mobile phone reduces uncertainty by making it faster and cheaper to seek information to solve problems that are encountered daily (Muturi, 2012). Women in the developing countries and especially USA and Sweden have adopted the mobile phone to access information about the markets for their products, thereby improving their businesses (Joseph, 2005). They make use of all applications in the mobile phone and have been able to reach out for better markets for their products thereby improving their livelihood. In Kenya, lack of access to information among entrepreneurs makes them less aware of the available market opportunities. Entrepreneurs still face different challenges in accessing markets as a result of inadequate market information, poor marketing research and poor capacity in marketing leading to discrepancy between the supply and demand (KIPPRA, 2006). All women entrepreneurs in Machakos agreed that their businesses have grown since they started using the mobile phone and that they made more profit from their businesses. This is a clear indication that when well harnessed, the mobile phone can lead to higher growth hence empowerment.

\section{CONCLUSIONS}

From the findings of the study, it can be concluded that women entrepreneurs have accepted the mobile phone as an important tool for running their businesses but they have not fully adopted all the services of the mobile phone and especially the advanced functions. Women engage in business in order to earn profits and the mobile phone mediates activities in the community to enable women entrepreneurs increase their profits. It was observed that the women entrepreneurs who have adopted and used mobile phone technology services generated high revenues. Furthermore, it was confirmed by respondents that the use of mobile phone reduced business operation costs. The respondents further argued that the flow of information between value chain actors allowed and continued to allow for the exchange of information without travelling.

Women entrepreneurs used mobile phone technology services to open new markets and for selling and buying of products. In addition to the above, results of the focus group discussions revealed that the mobile phone facilitated women entrepreneurs in coordinating their business processes. The use of phone was found to be a tool widely used to coordinate business activities anytime, anywhere.

\section{RECOMMENDATIONS}

Women entrepreneurs need to embrace the more advanced mobile technology in their businesses in order to make more profits and to be able to reach out to other markets. Technology has made the world a global 
Extent of Adoption And Usage of Mobile Phone Services in Empowering Women Entrepreneurs in..

village hence for one to remain relevant in the business world, they have to embrace it (Khalifa, 2002). The study has highlighted the potential benefits of using the advanced mobile phone services in entrepreneurship, therefore women entrepreneurs and especially in Machakos where the study was done need to embrace the mobile phone advanced services fully, without relying on the basic uses in order to reap the benefits of using the mobile phone in their business transactions and hence improve their enterprises.

Women opinion leaders should encourage and support their members to adopt and use mobile phone technology services, and do a follow up to make sure the members adopt it fully. This can be a standing agenda during their organized meetings. Since interpersonal communication seems to be the most commonly used medium of passing information, women entrepreneurs should be encouraged to share more information with their business colleagues and group members.

\section{REFERENCES}

[1]. Blumler 2011,Uses and gratification research - The public opinion quarterly 4th edition

[2]. Cherie Blair Foundation for Women (2012). Mobile Value Added Services: A Business Growth Opportunity for Women Entrepreneurs. Available from http://www.cherieblair foundation.org/ wp-content/uploads/2012/07/MobileValue-Added-Services-digital-report.pdf/. London: Cherie Blair

[3]. Chibba, M. (2009). Financial Inclusion, Poverty Reduction and the Millennium Development Goals, European Journal of Development Research, 213-230. Sinclair S, McHard F, Dobbie L.

[4]. Cracknell, (2004), The Daily Telegraph "ICT for empowerment". Manchester, UK.

[5]. Demombynes, G. and Thegeya, A. (2012) Kenya's mobile revolution and the promise of mobile savings, World Bank, Policy Research Working paper; WPS no 5988.

[6]. Donner, J. \& Escobari, M. (2010). A review of evidence on mobile use by micro and small Enterprises in developing countries. Journal of International Development. 22(5): 641-658.

[7]. Finmark Trust, (2008). Managing the risk of mobile banking technologies, London, UK.

[8]. Gakure, R. (2004) Women's Enterprises: Issues Impacting on Growth of Women's Enterprises in Kenya. Jomo Kenyatta University of Agriculture \& Technology.

[9]. Government of Kenya (GoK), 2013.Kenya Demographic and Development Survey 2011 - 2012. Nairobi, Kenya.

[10]. Government of Kenya ,2007,Kenya Vision 2030.A globally competitive and prosperous Kenya. Nairobi .Government printers

[11]. Government of Kenya ,2009,GoK.Economic survey report.Nairobi Government printers

[12]. Government of Kenya, (2005). Sessional paper No. 2 of 2005 on development Micro and Small enterprises for wealth and employment creation for poverty reduction. Nairobi: Government printer

[13]. Hamerman, P. 2010. Mobile Applications Will Empower Enterprise Business Processes. http://www.computerweekly.com/feature/Forrester-Research-Mobileapplications-will-empower enterprise-businessprocesses. Accessed on 2/7/2015.

[14]. Herrington, (2009), Authentic e-learning in higher education. Bonn, Germany.

[15]. Hisrich, R.D., Peters, M.P. (1992), Entrepreneurship: Starting, Developing and Managing a New Enterprise. New York, USA.

[16]. Huyer, S.Tatjana,S. (2003). Overcoming the gender digital divide: understanding ICTs and their potential for the empowerment of women. Synthesis paper presented to the UN United Nations International Research and Training Institute for the Advancement of Women.http://www.uninstraw.org/en/docs/gender_and_ict/Synthesis_P aper.pdf.

[17]. Ikiara, G.K. (2001) Economic Gloom Still persists: "Kenyans to Continue grappling with Unfulfilled expectations due to mismanagement" Special Report in Sunday Nation, 30 December 2001. Nairobi: Nation Press.

[18]. Imbaya, M. (2004) Entrepreneurial Disposition and Development of Female-Operated Enterprises in Mureithi 2005 Factors affecting internet use among micro-enterprises: an empirical study in Kariobangi light industries in Nairobi Kenya,

[19]. Joseph, L. (2005) Inter-city marketing network for women micro-entrepreneurs using cell phone: social capital brings economic development, Chennai. Centre for Science, Development \& Media Studies.

[20]. Kalundo, M. (2012) Use of Information and Communication Technologies by Women Entrepreneurs in Small and Micro Enterprises, Kenya Rural Entrepreneurial Programme, Nairobi, Kenya.

[21]. Kanyingi, J. M. (2011). The impact of financial deepening on Economic Growth in Kenya (Unpublished MBA Project). University of Nairobi.

[22]. Katz, E. (1959). "Mass Communications Research and the Study of Popular Culture: An Editorial Note on a Possible Future for this Journal". Departmental Papers (ASC): 1-6.

[23]. Khalifa, M.; Cheng, S.K.N. (2002), Adoption of mobile commerce: role of exposure. Proceedings of the 35th Hawaii International Conference on System Sciences

[24]. Kotelnikov 2007, Small and medium enterprise and ICT forward by Kim Hak-SU,UN

[25]. Kretschmer, T. (2012). Information and Communication Technologies and Productivity Growth: A Survey of the Literature. OECD Digital Economy Papers, No. 195. OECD Publishing. http://dx.doi.org/10.1787/5k9bh3jllgs7-en. Accessed on 2/7/2015

[26]. Levy, K and Windahl, C. (1985).The concept of audience activity - Media gratification research

[27]. Lynn, J.(2013) "Mobile phones help lift poor out of poverty: U.N. study". Reuters. Retrieved 2013-12-03.

[28]. Malhotra, Anju, Sidney Ruth Schuler, and Carol Boender. 2002. "Measuring Women's Empowerment as a Variable in International Development." International Center for Research on Women and the Gender and Development Group of the World Bank 
Extent of Adoption And Usage of Mobile Phone Services in Empowering Women Entrepreneurs in..

[29]. Maru 2004,ICT enabled information system for agricultural development in India - Case study ,India

[30]. Morawczynski 2009,Designing mobile money services lessons from M-pesa,Kenya

[31]. Mureithi, M. (2005) Factors affecting internet use among micro-enterprises: an empirical study in Kariobangi light industries in Nairobi Kenya, Nairobi.

[32]. Mutwiri, I. (2013) Mobile phone and rural livelihoods, context, level, dimension of use and challenges among smallholder farmers in Machakos County, (PHD thesis) University of Nairobi.

[33]. Porteous, D. (2006). The Enabling Environment for Mobile Banking in Africa, Report, Commissioned by Department for International Development -DFID

[34]. Reynolds, P.D., Bygrave, W.D., Autio, E., Cox, L.W. and Hay, M. (2004), Global Entrepreneurship Monitor (GEM): Executive Report, Babson College, London Business School and Ewing Marion Kaufman Foundation.

[35]. Svanaes, D., Alsos, O. A., \& Dahl, Y. (2010). Usability testing of mobile ICT for clinical Settings: Methodological and practical challenges. International Journal of Medical Informatics, 79(4), 24-34

[36]. UNDAW, (2001), Economic commission for Europe. Geneva, Switzerland.

[37]. Vaughan 2007,perspective on blended learning in higher education,University of Calgary,Canada. 